\title{
Jerami Padi Fermentasi sebagai Alternatif Solusi Pakan Sapi Berkualitas di Desa Majasari, Indramayu
}

\author{
Oleh : \\ Asep Suherman ${ }^{1)}$, Wiwik Ambarsari'2), Yudhi Mahmud ${ }^{3)}$, \\ Program Studi Agribisnis Fakultas Pertanian Universitas Wiralodra ${ }^{1,2)}$ \\ Program Studi Agroteknologi Fakultas Pertanian Universitas Wiralodra ${ }^{3)}$ \\ rizqi_ovie-suherman@yahoo.co.id ${ }^{1)}$, wiwikambarsari@yahoo.co.id ${ }^{2}$, \\ yudhi8527@gmail.com ${ }^{3)}$
}

\begin{abstract}
Abstrak
Tujuan pengabdian kepada masyarakat untuk menambah pengetahuan dan keterampilan pada masyarakat tentang fermentasi jerami padi sebagai alternatif pakan sapi berkualitas. Kegiatan ini dilaksanakan bulan Mei dan Agustus 2018 pada Kelompok Ternak Sapi Tunggal Rasa I dan II di Desa Majasari Kecamatan Sliyeg Kabupaten Indramayu. Metode pengabdian dengan pendekatan ceramah dan diskusi, demonstrasi, dan latihan pembuatan fermentasi jerami padi dengan urea dan dedak. Hasil kegiatan adalah masyarakat peternak sapi memiliki pengetahuan dan keterampilan tentang fermentasi jerami padi dan sapi menyukai hasil fermentasi jerami padi sehingga dapat menjadi alternatif solusi pakan berkualitas.
\end{abstract}

Kata kunci : pakan sapi, jerami padi fermentasi

\begin{abstract}
The purpose of community service is to increase knowledge and skills to the community about fermentation of rice straw as an alternative to quality cow feed. This activity was held in May and August 1918 in the Cattle Groups Tunggal Rasa I and II, Majasari Village, Sliyeg District, Indramayu Regency. The method is carried out by lecturing and discussion, demonstration, and practice of making fermented rice straw with urea and bran. The result of this service is that cattle farmers have the knowledge and skills about fermentation of rice straw and cows like rice straw fermentation so that they can fulfill a quality alternative feed solution.
\end{abstract}

Key words : cattle feed, fermentation of rice straw

\section{A. Pendahuluan}

Jerami padi merupakan produk samping tanaman padi yang tersedia dalam jumlah relatif banyak dibandingkan dengan produk samping pertanian lainnya dan terdapat hampir di setiap daerah di Indonesia. Ketersediaan jerami padi yang melimpah merupakan peluang untuk dimanfaatkan sebagai pakan sumber energi bagi ternak ruminansia (Antonius, 2009).

Kabupaten Indramayu terkenal sebagai salah satu lumbung padi nasional. Luas panen padi tahun 2015 sebesar 209.144 ha menghasilkan produksi gabah 
sebesar 1.465.740 ton (BPS Kabupaten Indramayu, 2016). Berdasarkan asumsi bahwa berat gabah sama dengan berat jerami (Suherman, 2017), maka di Kabupaten Indramayu akan diperoleh jerami padi sebanyak 1.465 .740 pada tahun 2015. Potensi ini cukup besar dalam penyediaan bahan pakan sumber serat, terutama pada musim kemarau (Suherman, 2017). Hanya dalam pemanfaatan jerami padi masih kurang, umumnya dibakar setelah panen pada musim kemarau dan dibenam pada musim penghujan. Jerami padi yang dimanfaatkan sebagai bahan pakan baru sekitar 31\% saja, 62\% dibakar atau dibenamkan dan sisanya sekitar 7\% untuk keperluan industri (Komar, 1984).

Manurut Suherman (2017) bahwa diasumsikan jerami padi yang dihasilkan 1 ha dapat menghidupi 2 ekor sapi dalam setahun ( 2 kali musim). Ini artinya bahwa sekitar 418.288 ekor sapi yang menjadi potensi ada di Indramayu tahun 2015 jika jerami padi dimanfaatkan semuanya. Kabupaten Indramayu dapat menjadi swasembada daging sapi, sebagai daerah eksportir daging sapi ke daerah lain. Pada kenyataannya bahwa Kabupaten Indramayu tahun 2015 tercatat hanya 11.092 ekor sapi potong (BPS Kabupaten Indramayu, 2016), tentunya potensi yang hilang sebanyak 407.196 ekor sapi.

Permasalahan selain belum optimalnya pemanfaatan jerami padi yang jumlahnya melimpah sebagai bahan pakan ternak terdapat pula kelemahannya, diantaranya adalah : kandungan proteinnya cukup rendah, kandungan lignin dan silika cukup tinggi sehingga daya cerna pakan ternak sapi rendah. Hasil analisa kandungan gizi jerami padi diantanaya $86 \%$ BK; $18,20 \%$ abu; 1,50\% LK, 30,90\% SK; 3,44\% PK; 32,20\% BETN, dan 1,180 Mkal/kg metabolisme energi. Nilai kecernaan bahan kering jerami padi sekitar 30\% (Ashari, dkk., 1996). Hal ini mengakibatkan konsumsi bahan kering menjadi rendah sekitar $2 \%$ berat badan ternak. Kondisi ini jika tanpa konsentrat tidak mungkin dapat meningkatkan produksi ternak dan dapat menurunkan produksi.

Menurut Sa'id (1996) bahwa hidrolisa hemiselulosa menghasilkan tiga jenis monosakarida, yaitu xylosa dan arabinosa (dalam jumlah banyak) serta glukosa (dalam jumlah sedikit). Hemiselulosa dapat difermentasi oleh beberapa mikroorganisme yang mampu menggunakan gula pentosa sebagai substrat. Dengan demikian untuk memperbaiki kelemahan kandungan gizi dan daya simpan 
yang cukup lama dari jerami padi diperlukan teknologi fermentasi biokimia (Syamsu, 2006).

Desa Majasari menjadi Desa Unggulan, dengan pengelolaan BUMDes yang baik menggandeng pihak perbankan lewat program penggemukan sapi para keluarga Tenaga Kerja Indonesia (TKI) khusunya pada Kelompok Ternak Tunggal Rasa, yang semula berjumlah 22 ekor sapi hingga kini berkembang sudah mencapai 200 ekor (www.berdesa.com, 2018). Menurut Badan Pusat Statistik (2017) bahwa luas sawah Desa Majasari sebesar 201,043 ha dan produksi padi 29.590,00 ton gabah kering giling (GKG) pada tahun 2016. Ini artinya bahwa Desa Majasari memiliki limbah jerami padi sebesar 29.590,00 ton (100\% produksi padi menurut Suherman, 2017) selama setahun. Ini menjadi potensi pakan sapi berkualitas yang cukup besar bagi Desa Majasari. Selain itu, limbah dedak padi sebesar $1.490,05$ ton $(5,86 \%$ dari GKG menurut Salim, 2014) adalah potensi sebagai sumber protein pakan sapi dalam setahun di tahun 2016.

Oleh karenanya perlu dilakukan sosialisasi melalui program pengabdian mengenai fermentasi jerami padi sebagai pakan ternak sapi berkualitas pada Kelompok Ternak Tunggal Rasa di Desa Majasari.

Kegiatan pengabdian kepada masyarakat ini bertujuan untuk memberikan tambahan pengetahuan dan keterampilan dalam kualitas pakan ternak sapi yang berasal dari jerami padi fermentasi sehingga diharapkan peternak sapi dapat memahami betapa pentingnya pemberian pakan yang berkualitas untuk pertumbuhan sapi dalam usaha ternaknya. Dengan demikian peternak sapi di Kelompok Ternak Sapi Tunggal Rasa diharapkan dapat menerapkan secara berkelanjutan dalam usaha ternak sapinya untuk meningkatkan kualitas daging sapinya sehingga produksi daging sapi berkualitas dan meningkat sehingga pendapatan peternak sapi meningkat.

Manfaat kegiatan pengabdian kepada masyarakat ini diharapkan:

1. Anggota Kelompok Ternak Sapi Tunggal Rasa memperoleh pengetahuan dan keterampilan tetang pemanfaatan jerami padi sebagai pakan ternak sapi dan pentingnya kualitas pakan yang diberikan kepada ternak melalui teknologi fermentasi jerami padi baik dari segi nutrisinya dan lama penyimpannya. 
2. Sebagai forum diskusi antara peternak sapi Kelompok Ternak Sapi Tunggal Rasa dengan perguruan tinggi dalam transfer teknologi.

\section{B. Metode}

Penentuan sasaran dengan cara purposive karena Desa Majasari Kecamatan Sliyeg Kabupaten Indramayu sebagai daerah potensi pengembangan sapi, yaitu pada anggota Kelompok Ternak Sapi Tunggal Rasa yang berjumlah 24 orang. Kegiatan ini dilaksanakan pada tanggal 20-21 Mei 2018 di Kelompok Ternak Sapi Tunggal Rasa I dan tanggal 9-10 Agustus 2018 di Kelompok Ternak Sapi Tunggal Rasa II.

Metode yang dilakukan, yaitu ceramah, demonstrasi, dan pelatihan berkaitan dengan pembuatan jerami padi fermentasi dan aplikasi pada sapi. Metode kegiatan yang dilakukan adalah :

1. Ceramah

Metode ceramah di sini dilakukan oleh narasumber memberikan pemahaman betapa pentingnya kualitas pakan ternak sapi yang berasal dari jerami padi dengan cara pengolahan melalaui fermentasi. Kemudian dilanjutkan dengan diskusi atau tanya jawab dari pengalaman-pengalaman peserta atau permasalahan-permasalahan peserta di seputar pakan ternak sapi.

2. Demonstrasi

Metode demonstrasi, yaitu suatu cara yang dilakukan narasumber untuk memberikan contoh atau memperlihatkan secara langsung proses pembuatan fermetnasi jerami padi yang menggunakan urea dan fermentasi jerami padi yang menggunakan dedak padi.

3. Latihan

Metode latihan, yaitu suatu cara yang dilakukan oleh peserta secara langsung yang didampingi narasumber dengan tujuan agar peserta lebih memahami dan meningkatkan keterampilan dalam pembuatan fermentasi jerami padi yang menggunakan urea dan fermentasi jerami padi yang menggunakan dedak padi.

Langkah-Langkah pelaksanaan kegiatan pengabdian ini adalah :

1. Tahapan Persiapan

Pada tahapan persiapan kegiatan pengabdian ini dilakukan koordinasi mengenai 
program dengan Kepala Desa Majasari dan Kelompok Ternak Sapi Tunggal Rasa sebagai mitra.

2. Tahapan Pelaksanaan

Pada tahapan pelaksanaan pengabdian ini dilakukan sosialisasi dengan metode ceramah dimaksudkan untuk memberikan tambahan pengetahuan dan keterampilan pada anggota kelompok ternak sapi tentang kualitas pakan dari jerami padi yang difermetnasi. Kemudian dilanjutkan dengan metode demonstrasi sekaligus latihan pembuatan fermentasi jerami padi yang menggunakan campuran urea dan fermentasi jerami padi yang menggunakan dedak padi, selain dari campuran bahan lainnya seperti EM-4.

3. Tahapan Evaluasi

Pada tahapan evaluasi ini melihat hasil dari pembuatan jerami fermentasi yang dilakukan hasil demonstrasi dan latihan pada kegiatan pengabdian ini.

\section{Hasil dan Pembahasan}

1. Tahap Persiapan

Kegiatan sosialisasi pengabdian ini tentunya terlebih dahulu telah melakukan koordinasi dengan Kepala Desa dan Ketua kelompok Ternak Sapi Tunggal Rasa di Desa Majasari Kecamatan Sliyeg Kabupaten Indramayu untuk mempersiapkan kegiatan pengabdian ini berjalan dalam pembagian tugas dan kesepakatan waktu pelaksanaan. Ketua Kelompok Ternak Tunggal Rasa mempersiapkan anggotanya dan lokasi di kandang sapi untuk ceramah sekaligus tempat demonstrasi dan latihan. Sedangkan bagi tim nara sumber Faperta Unwir mempersiapkan materi yang akan disampaikan dan bahan-bahan yang perlu didemonstrasikan jika tidak terdapat pada kelompok ternak.

2. Tahap Pelaksanaan Kegiatan

Pelaksanaan kegiatan diantaranya ceramah dan diskusi, demonstrasi, dan latihan di Kantor Kelompok Tunggal Rasa I dan II seta kandang sapi.

\section{Fermentasi Jerami Padi dengan dua cara}

Permasalahan pada rendahnya kualitas jerami padi ini perlunya suatu 
teknologi tertentu agar tersedia sepanjang masa, yaitu dengan cara fermentasi amoniasi menggunakan urea dan fermentasi menggunakan dedak. Kedua fermentasi ini menggunakan bahan bakteri. Fermentasi dilakukan dengan cara menambahkan bahan yang mengandung mikroba probiotik, lignolitik, selulolitik, lipolitik, dan fiksasi nitrogen non simbiotik (seperti : starbio, starbioplus, atau EM4/effektivitas microorganisme-4). Tujuan dari pengolahan jerami padi melalui fermentasi adalah selain meningkatkan kualitas kandungan nutrisi jerami padi dan jerami fermentasi ini dapat disimpan lama hingga satu tahun dengan maksud mengatasi permasalahan ketersediaan pakan hijauan di musim kemarau.

1. Fermentasi Jerami Padi yang menggunakan urea

Fermentasi jerami padi menggunakan urea biasa disebut proses amoniasi, yaitu perlakuan alkali karena urea yang ditambah pada pakan mengalami ureolitik menjadi NH3 membentuk basa NH4OH. Suhu lingkungan yang tinggi akan membantu proses ureolitik (Sutardi, 1997). Kemudian proses ini mampu melonggarkan ikatan lignoselulosa sehingga mudah dicerna oleh bakteri rumen dan dapat memasok nitrogen untuk pertumbuhan bakteri tersbut (Leng, 1991). Selain itu, dapat meningkatkan kadar protein kasar dari 4\% menjadi 14\% (Nurhaita, dkk., 2007)

2. Fermentasi Jerami Padi yang menggunakan mikroba

Fermentasi secara biologis pada jerami padi dengan menggunakan mikroba tertantu. Fermentasi ini adalah proses pengolahan bahan dengan bantuan mikroba yang mampu memecah komponen komplek menjadi bentuk yang lebih sederhana, misalnya selulosa dan hemiselulosa menjadi glukosa. Bahan yang mengalami fermentasi biasanya mempunyai nilai gizi yang lebih baik dari asalnya. Hal ini tidak hanya disebabkan oleh mikroorganisme yang memecah komponen- komponen komplek menjadi zat-zat yang sederhana sehingga mudah dicerna, tetapi mikroorganisme juga dapat mensintesa beberapa vitamin seperti riboflavin, vitamin B 12, pro vitamin A dan faktor pertumbuhan lainnya, serta dapat terjadi pemecahan karbohidrat oleh enzim tertentu misalnya hemisellulosa, sellulosa, dan polimer-polimernya menjadi gula sederhana atau turunannya (Winarno, et al., 1980). Pada proses fermentasi enzim yang dihasilkan oleh mikroorganisme akan melakukan oksidasi, reduksi dan reaksi kimia lainnya 
sehingga terjadi perubahan kimia pada suatu substrat organik dengan menghasilkan suatu produk tertentu (Smith and Siregar, 1983). Fermentasi dapat memperbaiki sifat tertentu dari bahan seperti menjadi lebih mudah dicerna, lebih tahan disimpan dan dapat menghilangkan senyawa racun yang terkandung di dalammya, sehingga nilai ekonomis bahan dasarnya menjadi lebih baik (Saono,1988). Selain itu fermentasi juga dapat meningkatkan kandungan protein bahan karena tubuh kapang itu sendiri mengandung 19-38\% protein (Jamarun, 2000; Jamarun dan Agustin, 1999).

\section{Pentingnya Kualitas Jerami Padi Fermentasi}

Hasil penelitian yang telah dilakukan oleh Syamsu (2006) dalam fermentasi jerami, menyatakan bahwa :

1. Komposisi nutrisi jerami padi yang telah difermentasi menggunakan starter mikroba (starbio) sebanyak $0,06 \%$ dari berat jerami padi, secara umum memperlihatkan peningkatan kualitas dibanding jerami padi yang tidak difermentasi.

2. Kadar protein kasar meningkat dari $4,23 \%$ menjadi $8,14 \%$, dan penurunan kadar serat kasar. Ini mengindikasikan bahwa starter mikroba proteolitik menghasilkan enzim protease yang dapat merombak protein menjadi polipeptida kemudian menjadi peptida sederhana.

3. Kemudian terjadi penurunan kadar dinding sel (NDF) jerami padi dari $73,41 \%$ menjadi $66,14 \%$. Ini menunjukkan terjadi pemutusan ikatan lignoselulosa dan hemiselulosa jerami padi. Mikroba lignolitik dalam starter mikroba membantu perombakan ikatan lignoselulosa sehingga selulosa dan lignin dapat terlepas dari ikatan tersebut oleh enzim lignase. Ini ditunjukkan dengan penurunan kandungan selulosa dan lignin pada jerami padi yang difermentasi.

Menurunnya kadar lignin menunjukkan selama fermentasi terjadi penguraian ikatan lignin dan hemiselulosa. Lignin merupakan benteng pelindung fisik yang menghambat daya cerna enzim terhadap jaringan tanaman dan lignin berikatan erat dengan hemiselulosa. Kemudian dengan tanda penurunan kadar NDF menunjukkan telah terjadi pemecahan selulosa dinding sel sehingga pakan akan menjadi lebih mudah dicerna oleh ternak dan diserapnya lebih banyak.

\section{Demonstrasi dan Latihan}


Demonstrasi dan latihan yang dilakukan narasumber dan peserta dilakukan, yaitu (1) pembuatan fermentasi jerami padi yang menggunakan campuran urea dan (2) pembuatan fermentasi jerami padi yang menggunakan campuran dedak. Adapun bahan, alat, dan cara pembuatan jerami padi fermentasi pada saat demonstrasi dan latihan dilakukan adalah sebagai berikut :

\section{A. Fermentasi Jerami Padi Yang Menggunakan Campuran Urea}

Bahan yang dibutuhkan dalam pembuatan 1 ton jerami padi hijau/kering adalah :

\section{1 liter EM-4}

$2 \mathrm{~kg}$ ( 2 bungkus) probiotik

2 liter molase

$2,5 \mathrm{~kg}$ urea

10 liter air

Alat yang dibutuhkan :

1 buah ember ukuran 25 liter

2 buah ember ukuran 5 liter

1 buah pengaduk

1 buah terpal ukuran $4 \mathrm{~m} \times 6 \mathrm{~m}$

1 buah terpal ukuran $6 \mathrm{~m} \times 8 \mathrm{~m}$

Cara pembuatan bahan untuk pencampuran fermentasi :

1. Campurkan menjadi satu antara $2,5 \mathrm{~kg}$ urea dan $2 \mathrm{~kg}$ probitik dalam 1 ember ukuran $5 \mathrm{~kg}$.

2. Campur menjadi satu antara 2 liter molase, 1 liter EM-4, dan 10 liter air dalam 1 ember $25 \mathrm{~kg}$.

Cara aplikasi pembuatan fermentasi dengan jerami padi :

1. Pertama-tama hamparkan terpal yang berukuran $4 \mathrm{~m} \times 6 \mathrm{~m}$

2. Kemudian jerami ditimbang sebanyak 1 ton terlebih dahulu.

3. Jejerkan jerami setebal $20 \mathrm{~cm}$ dengan arah sejajar agar saat panen mudah dilakukan dan diinjak-injak agar padat merata terhindar dari ruang udara.

4. Selanjutnya diberikan campuran urea dan probiotik secara merata (1/3 bagian)

5. Kemudian disiram campuran Em-4+molase+air dengan cara diciprat-ciprat secara merata di tempat yang telah ditaburi campuran urea dan probiotik. 
6. Kemudian diulang kembali sampai jerami habis dan campuran bahan fermentasi habis (biasanya 2 lapis lagi dari 1 ton)

7. Kemudian buat adonan campuran bahan lagi untuk ukuran 1 ton jerami padi lagi jika akan membuat 1 ton berikutnya yang ditumput di atas 1 ton sebelumnya.

8. Lakukan hal yang sama seperti di atas sebanyak 1 ton jerami

9. Terakhir sisakan jerami sedikit untuk melapisi di bagian atasnya.

10. Kemudian ditutup rapat sekali sehingga kedap udara (sifat anaerob) sampai 14 hari.

\section{B. Fermentasi Jerami Padi Yang Menggunakan Campuran Dedak}

Bahan yang dibutuhkan dalam pembuatan 1 ton jerami padi hijauan/kering:

1. Dedak $=100 \mathrm{~kg}$

2. $\mathrm{EM} 4=2$ botol

3. Molase $=5$ liter

4. Garam = seperlunnya

5. Air $=50$ liter

Alat yang dibutuhkan :

2 buah ember / jolang ukuran besar

4 buah ember ukuran 5 liter

1 buah pengaduk

1 buah terpal ukuran $4 \mathrm{~m} \times 6 \mathrm{~m}$

1 buah terpal ukuran $6 \mathrm{~m} \times 8 \mathrm{~m}$

Cara pembuatan bahan untuk pencampuran fermentasi 1 ton jerami padi:

1. Siapkan dedak sebanyak $100 \mathrm{~kg}$

2. Campur menjadi satu antara 5 liter molase, 4 liter EM-4, dan 50 liter air dalam jolang besar.

$\underline{\text { Cara aplikasi pembuatan fermentasi dengan jerami padi } 1 \text { ton jerami padi: }}$

1. Pertama-tama hamparkan terpal yang berukuran $4 \mathrm{~m} \times 6 \mathrm{~m}$ dan selipkan terpal ukuran $6 \mathrm{~m} \times 8 \mathrm{~m}$

2. Kemudian jerami ditimbang sebanyak 1 ton terlebih dahulu.

3. Jejerkan jerami setebal $20 \mathrm{~cm}$ dengan arah sejajar agar saat panen mudah dilakukan dan diinjak-injak agar padat merata terhindar dari ruang udara. 
4. Selanjutnya ditaburkan dedak (1/3)

5. Kemudian disiram campuran EM- 4 + molase + air + garam dengan cara diciprat-ciprat secara merata di tempat yang telah ditaburi dedak.

6. Kemudian diulang kembali sampai jerami habis dan campuran bahan fermentasi habis (biasanya 2 lapis lagi dari 1 ton).

7. Terakhir sisakan jerami sedikit untuk melapisi di bagian atasnya.

Proses fermentaasi jerami padi yang menggunakan urea berlangsung selama 14 hari, yang terdiri atas jerami padi, urea, probiotik, EM4, molase, dan air secukupnya. Fermentasi jerami padi yang menggunakan dedak padi berlangsung selama 21 hari, yang terdiri dari jerami padi, dedak padi, EM4, molase, dan air secukupnya. Ciri hasil fermentasi jerami padi yang memiliki kualitas baik adalah ciri khas bau amonia dengan tekstur yang masih utuh, jerami padi terlihat berwarna kuning namun setelah beberapa saat dianginkan udara terbuka warnanya berubah menjadi kecoklatan, terlihat hasil fermentasi nya sangat baik dan dapat diberikan sebagai pakan kepada sapi.

Pada saat kegiatan latihan yang dilakukan peserta Kelompok Ternak Sapi Tunggal Rasa melakukan pengolahan fermentasi jerami padi secara individu, sebagai narasumber mendampingi, kemudian teknik pemberian pakan hasil fermentasi jerami padi. Hasil fermentasi jerami padi ini dapat diberikan kepada ternak sapi secara langsung dengan syarat setelah penutup fermentasi dibuka dan diangin-anginkan beberapa saat agar gas dan panasnya keluar sampai dingin. Perlu diperhatikan waktu adaptasi untuk pakan yang baru, yaitu dengan cara memberikan hijauan yang biasa dimakan seperti terlebih dahulu rumput dicampur dengan jerami padi hasil fermentasi secara bertahap sampai proporsi jerami padi fermentasi lebih banyak dari rumput dan nantinya dapat menggantikan rumput 100 persen. Kemudian perlu dipercikan molase (limbah tebu) pada pakan jerami padi fermentasi untuk meningkatkan gairah makan ternak sapi.

\section{Tahap Evaluasi}

Hasil dari evaluasi kegiatan pengabdian ini dapat diidentifikasikan faktor pendukung dan penghambat dalam melaksanakan program pengabdian kepada masyarakat, diantaranya adalah :

\section{Faktor Pendukung}


a. Adanya nara sumber dari bidang agroteknologi dan agribisnis Fakultas Pertanian Universitas Wiralodra.

b. Adanya dukungan Kepala Desa dan para stafnya baik dari materi, tenaga, dan waktunya dari tahap persiapan sampai selesai pelaksanaan kegiatan pengabdian ini.

c. Kesediaan dan kesungguhan anggota Kelompok Ternak Sapi Tunggal Rasa untuk mengikuti kegiatan pengabdian ini dalam pembuatan fermentasi jerami padi sebagai pakan ternak sapi.

d. Ketersediaan dana dari Universitas Wiralodra

2. Faktor Penghambat

a. Pengetahuan anggota Kelompok Ternak Sapi Tunggal Rasa mengenai pengolahan jerami padi dengan cara fermentasi bervariasi karena pengalaman peternak dalam beternak sapi pun bervariasi mulai dari 1 tahun sampai 6 tahun.

b. Umur peternak bervariasi, mulai dari 30 tahun sampai 70 tahun sehingga pemahamannya bervariasi dalam menangkap materi yang disampaikan narasumber.

c. Kehadiran peserta dari Kelompok Ternak Sapi Tunggal Rasa tidak semua karena kesibukan dalam aktifitas sehari-hari terutama mencari pakan hijauan untuk ternak sapinya karena walaupun berkelompok dalam satu kandang masih dilakukan manajemen kepengurusan masing-masing dalam berusaha ternak sapi, belum secara bersama-sama.

d. Keterbatasan waktu tentunya belum cukup dalam pelaksanaan kegiatan pengabdian ini, terutama dalam sosialisasi penyampaian materi. Ini terlihat banyaknya pertanyaan-pertanyaan dari peserta.

\section{Kesimpulan dan Saran}

Kegiatan pengabdian ini berjalan dengan baik dan dapat memberikan tambahan pengetahuan dan keterampilan pada peserta khususnya anggota Kelompok Ternak Sapi Tunggal Rasa mengenai pakan yang berkualitas berbasis jerami padi melalui praktek fermentasi secara langsung dan dicobakan langsung kepada ternak sapi. Jerami padi fermentasi baik yang menggunakan urea ataupun 
yang dedak cukup disukai ternak sapi dan dapat menjadi suatu alternatif solusi pakan berkualitas saat pakan hijauan sulit diperoleh terutama pada musim kemarau karena tahan lama untuk disimpan.

Saran yang dapat disampaikan agar anggota Kelompok Ternak Sapi Tunggal Rasa tetap melakukan pengolahan jerami padi berkelanjutan sebagai alternatif pakan berkualitas perlu ditindaklanjuti dengan pengabdian kepada masyarakat yang berkaitan dengan penguatan kelembagaan peternak sapi sehingga terbentuk kebersamaan anggota dalam penguatan kelembagaan kelompok, diantaranya manajemen penjadwalan dan pembagian tugas dalam penyediaan pakan ternak sapi, mulai dari pengumpulan jerami pada musim panen raya, pembuatan fermentasi jerami padi, dan pemberian pakan pada ternak sapi.

\section{UCAPAN TERIMA KASIH}

Kami ucapkan terima kasih kepada pimpinan Universitas Wiralodra yang telah mendukung pendanaan pada kegiatan pengabdian ini pada Masyarakat Desa Majasari Kecamatan Sliyeg Kabupaten Indramayu.

\section{DAFTAR PUSTAKA}

Antonius, 2009. Pemanfaatan Jerami Padi Fermentasi Sebagai Substitusi Rumput Gajah dalam Ransum Sapi. JITU Vol 4. Th 2009: 270-277.

Ashari, E., Juarini, Sumanto, B. Widodo dan Suratman. 1996. Pedoman Analisis Potensi Wilayah Penyebaran dan Pengembangan Peternakan. Kerjasama Direktorat Bina Penyebaran dan Pengembangan Peternakan. Direktorat Jenderal Peternakan dengan Balai Penelitian Ternak. Badan Penelitian dan Pengembangan Pertanian. Jakarta.

Badan Pusat Statistik. 2016. Kabupaten Indramayu Dalam Angka. BPS. Indramayu.

Jamarun, N. 2000. Biokonversi serat sawit dengan Aspergillus niger sebagai pakan ternak ruminansia. Laporan Penelitian Hibah Bersaing Perguruan Tinggi VIII. Tahun anggaran 1999/2000. Fakultas Peternakan Universitas Andalas, Padang.

Jamarun, N. dan F. Agustin, 1999. Bioproses Jerami Padi dengan Trichoderma harzianum Sebagai Bahan Pakan Ternak. Proseding Seminar Ilmiah Tahunan Perhimpunan Mikrobiologi Indonesia di Padang 23 Agustus 1999.

Komar, A. 1984. Teknologi Pengolahan Jerami sebagai Makanan Ternak. Cetakan Pertama. Yayasan Dian Grahita. Bandung-Indonesia.

Leng, R. A. 1991 Application of biotechnology of nutrition of animal in developing countries. FAO. Animal Production and Health paper. 
Nurhaita, N. Jamarun, R. Saladin, L Warly dan Mardiati Z. 2007. Efek beberapa metoda pengolahan limbah daun kelapa sawit terhadap kandungan gizi dan kecernaan secara invitro. J. Ilmu-Ilmu Pertanian Indonesia No 2: 139144.

Salim, Agus. 2014. Analisis Persentase Beras, Menir, Dedak, dan Sekam dari Gabah Kering Giling dalam Usaha Jasa Penggilingan Padi di Kecamatan Sliyeg Tahun 2014. Skripsi. Program Studi Agribisnis Fakultas Pertanian Universitas Wiralodra. Kabupaten Indramayu Provinsi Jawa Barat.

Saono, S. 1988. Pemanfaatan Jasad Renik dalam Pengolahan Hasil Sampingan Produksi Pertanian. Berita LIPI.

Sa'id, G. 1996. Penanganan dan Pemanfaatan Limbah Kelapa Sawit.

Smith. F. W and M. Siregar. 1983. Sulfur requirement of tropical forages. Sulfur in South East Asean and South Pasific Agriculture. Research for Development Seminar, Ciawi Bogor. Mey 23 - 27, 1983.

Suherman, A. 2017. Prospek Pengembangan Integrasi Tanaman Ternak. Badan Penelitian dan Pengembangan Pertanian. Bogor.

Sutardi, T. 1997. Peluang dan tantangan pengembangan ilmu-ilmu nutrisi ternak. Orasi Ilmiah Guru besar Tetap Ilmu Nutrisi Ternak. Fakultas Peternakan Institut Pertanian Bogor, Bogor.

Syamsu, J. 2006. Kajian Penggunaan Starter Mikroba dalam Fermentasi Jerami Padi Sebagai Sumber Pakan Pada Peternakan Rakyat di Sulawesi Tenggara. Pada Seminar Nasional Bioteknologi Puslit Bioteknologi LIPI. Bogor.

Winarno, F. G., S. Fardiaz and D. Fardiaz. 1980. Pengantar Teknologi Pangan. PT. Gramedia.

\section{FOTO DOKUMENTASI}

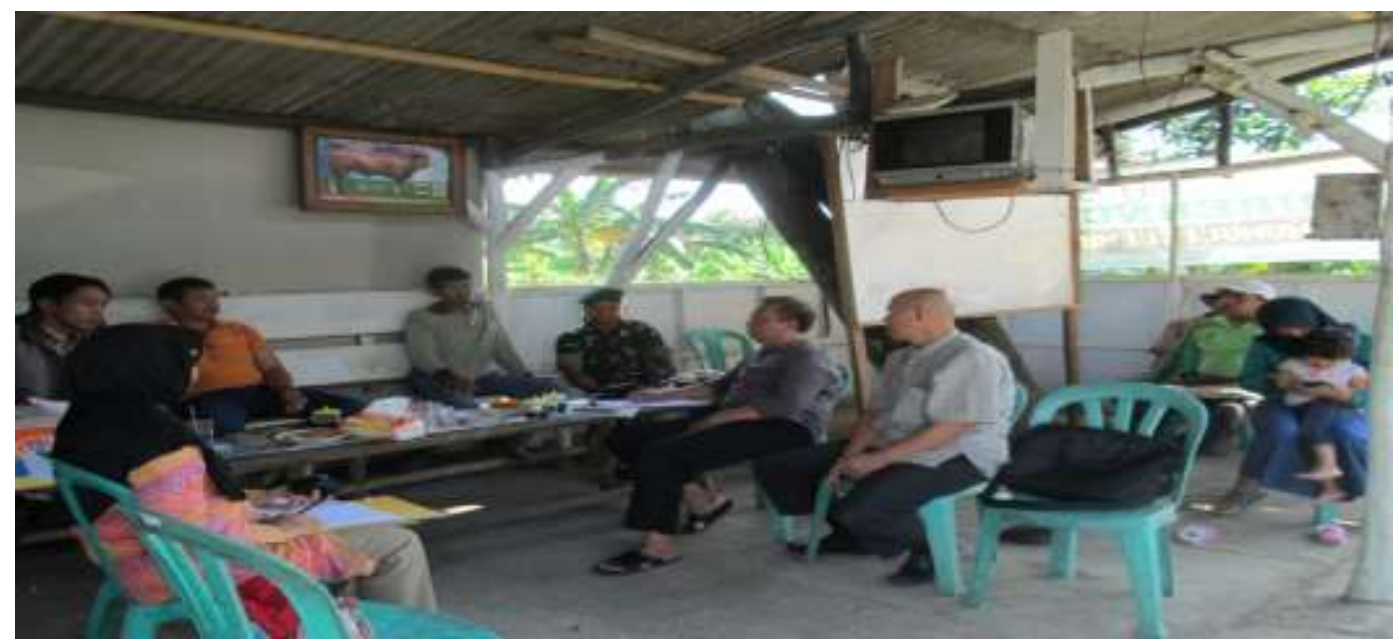

Gambar 1. Sosialisasi Kegiatan Pengabdian Kepada Masyarakat

Acara sosialisasi berkaitan dengan manfaat penggunaan limbah jerami padi yang difermentasikan sebagai pakan ternak sapi. Dihadiri kepala desa, dosen peternakan unpad, anggota TNI, dan anggota kelompok peternak sapi. Bentukan acara ini diskusi. 


\section{ABDI WIRALODRA

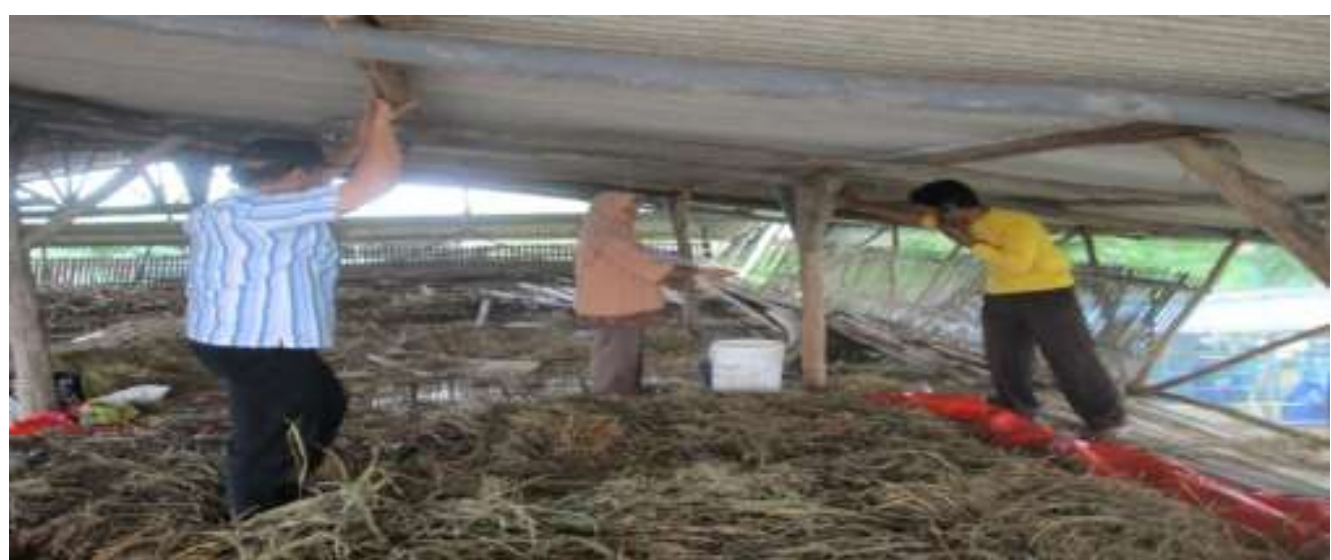

Gambar 2. Demonstrasi dan Latihan Fermentasi Jerami Padi oleh Narasumber dan Ketua Kelompok Ternak Sapi Tunggal Rasa

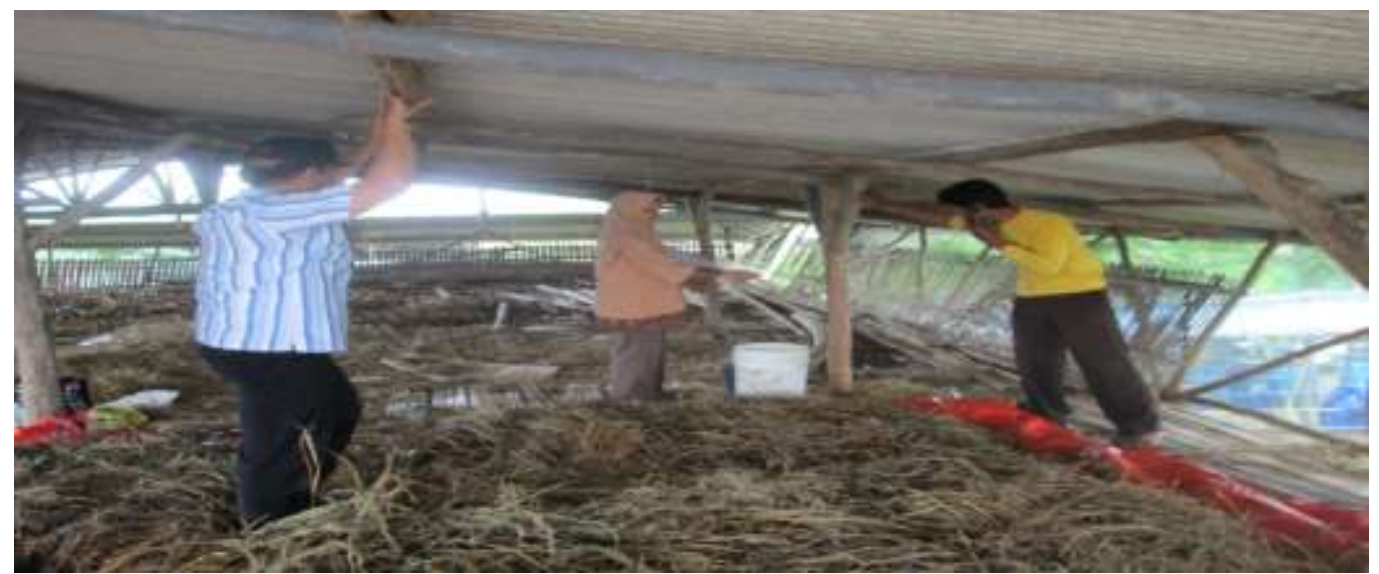

Gambar 3. Demonstrasi dan latihan Fermentasi Jerami Padi oleh Narasumber dan Ketua Kelompok Ternak Sapi Tunggal Rasa

Acara pembuatan fermentasi jerami padi di atas kandang sapi sebagai tempat penyimpanan pakan ternak sapi. Kegiatan ini dilakukan oleh 2 orang nara sumber dan seorang ketua kelompok ternak sapi tunggal rasa. Bentukan kegiatan ini demonstrasi sekaligus pelatihan.

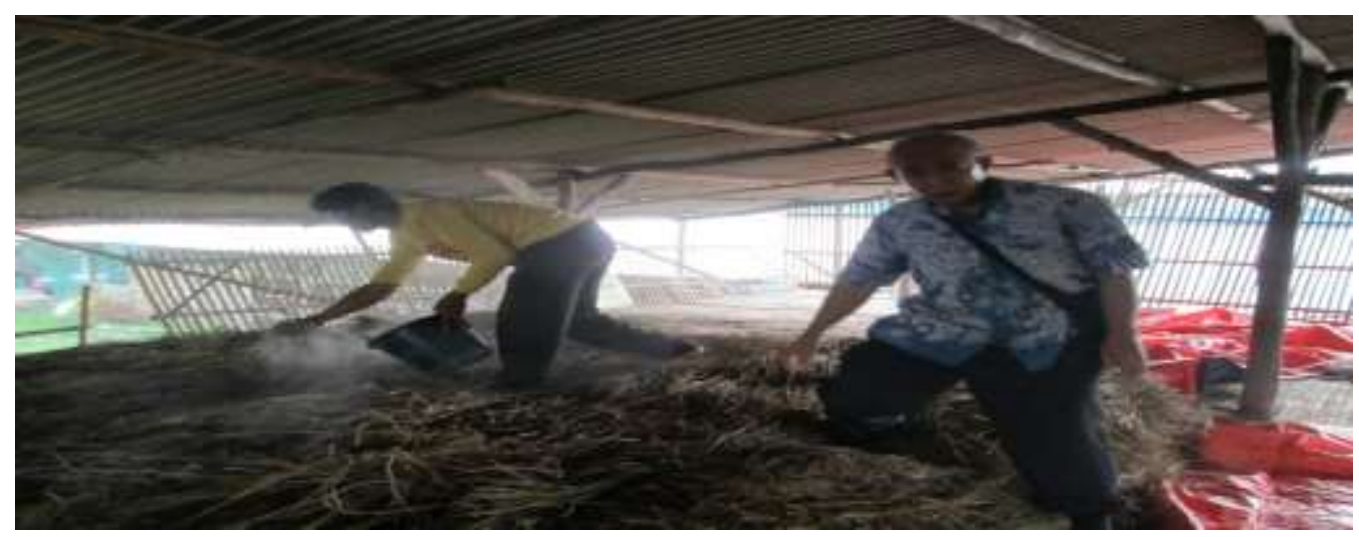

Gambar 4. Demonstrasi dan Latihan Proses Fermentasi Jerami Padi oleh Narasumber dan Ketua Kelompok Ternak Sapi Tunggal Rasa 
Tahapan lanjutan pembuatan fermentasi jerami padi di atas kandang sapi sebagai tempat penyimpanan pakan ternak sapi. Kegiatan ini dilakukan oleh seorang ketua tim pengabdian dan anggota tim sebagai nara sumber. Bentukan kegiatan ini demonstrasi sekaligus pelatihan.

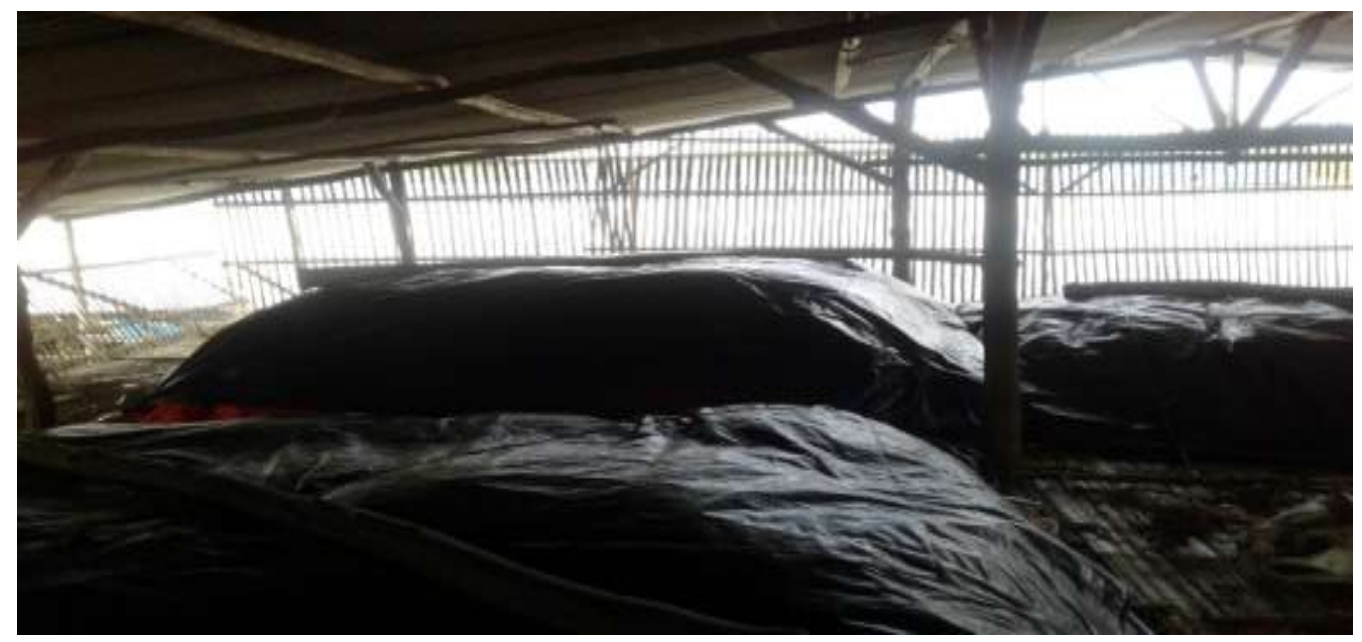

Gambar 5. Proses Fermentasi Jerami Padi Berlangsung selama 14 dan 21 Hari

Hasil pembuatan fermentasi yang dilakukan oleh narasumber dan peserta yang sedang diinkubasi selama 14 hari yang menggunakan urea dan 21 hari yang menggunakan dedak. Bentukan kegiatan ini inkubasi dan mengevaluasi hasil demonstrasi dan pelatihan dari fermentasi jerami padi yang telah dibuat.

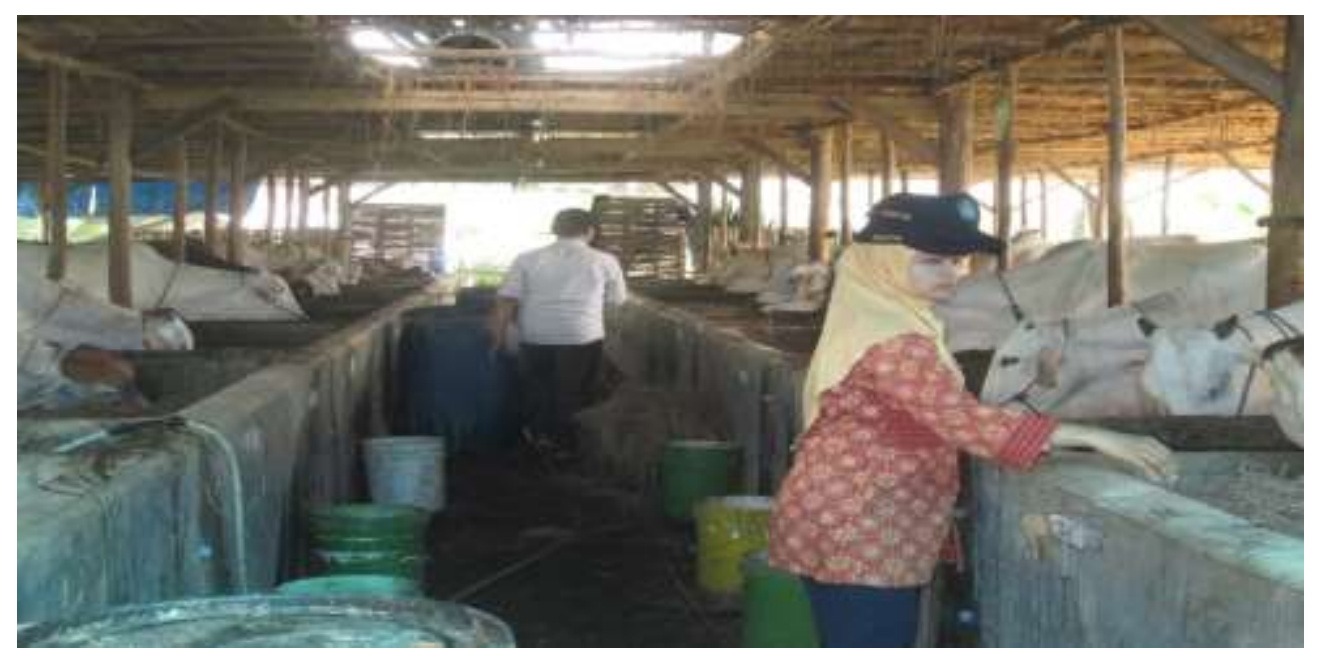

Gambar 6. Narasumber sedang mengaplikasikan pakan jerami padi fermentasi Pada Sapi milik Kelompok Ternak Sapi Tunggal Rasa

Acara pemberian pakan sapi dari hasil fermentasi jerami padi yang telah dibuat pada saat demonstrasi dan pelatihan. Kegiatan ini dilakukan oleh narasumber untuk melihat respon ternak sapi. Benrukan kegiatan demontrasi dan pelatihan. 
